\section{Defoliation and Infestation of Cucurbita pepo Genotypes by Diabroticite Beetles}

\author{
Michael P. Hoffmann ${ }^{1}$ \\ Department of Entomology, Cornell University, Ithaca, NY 14853
}

\author{
Richard W. Robinson ${ }^{2}$ \\ Department of Horticultural Sciences, Cornell University, New York State \\ Agricultural Experiment Station, Geneva, NY 14456
}

Margaret M. Kyle ${ }^{1}$

Department of Plant Breeding, Cornell University, Ithaca, NY 14853

\section{Jonathan J. Kirkwyland ${ }^{3}$ \\ Department of Entomology, Cornell University, Ithaca, NY 14853}

\section{Additional index words. cucumber beetle, corn rootworm, breeding, squash, pumpkin, trap crops}

\begin{abstract}
Seventy-six Cucurbita pepo L. cultivars and breeding lines were evaluated under field conditions for infestation levels and defoliation (leaf area consumed by beetles) by adult diabroticite beetles in 1992 and 1994. Striped and spotted cucumber beetles, Acalymma vittatum (F.) and Diabrotica undecimpunctata howardi Barber, respectively, were most common, but some western and northern corn rootworms, $D$. virgifera virgifera LeConte and $D$. barberi Smith and Lawrence, respectively, also were present. In general, pumpkin, delicata, acorn winter squash, scallop, and yellow straightneck summer squash types were the least infested and defoliated. Caserta/yellow, zucchini, caserta/zucchini, caserta, and precocious yellow straightneck types were the most infested and defoliated. The number of beetles per plant was correlated $(r \geq 0.72)$ with leaf defoliation and proportion of plants infested, indicating that beetle infestation is a good predictor of damage. The cultivars and breeding lines that were the least infested and defoliated can be used in breeding programs to develop desirable genotypes with reduced beetle preference. Conversely, those genotypes that were highly preferred have potential as trap crops for these beetle pests.
\end{abstract}

The striped and spotted cucumber beetles are important worldwide pests of many species of the Cucurbitaceae (Metcalf and Metcalf 1992). Infestations of adult cucumber beetles can destroy young plants and vector bacterial wilt and other diseases (Gergerich et al., 1986; Rand, 1916). Two related species, the adult western corn rootworm and the northern corn rootworm, also infest cucurbits. Howe et al. (1976) and Bach (1977) reported the western corn rootworm to be the dominant species on cucurbits in the midwestern United States, and in some years it is the dominant species in New York (Hoffmann, 1993).

Because of the potential losses associated with feeding damage to emerging plants and the transmission of diseases, cucumber beetle

Received for publication 12 Oct. 1995. Accepted for publication 9 Jan. 1996. Research conducted at Cornell Univ., Dept. of Entomology Research Farm, Freeville, N.Y. This research was supported in part by a grant from the New York State Integrated Pest Management Program. The cost of publishing this paper was defrayed in part by the payment of page charges. Under postal regulations, this paper therefore must be hereby marked advertisement solely to indicate this fact.

${ }^{1}$ Assistant Professor.

${ }^{2}$ Professor.

${ }^{3}$ Technician.
1986), we used field evaluations of beetle damage and leaf defoliation because it was the simplest and most economical screening method available.

\section{Materials and Methods}

The genotypes used in 1992 and 1994 were selected to represent the major C. pepo market classes in summer squash: yellow straightneck, precocious yellow straightneck, striped (caserta type), green (zucchini type), scallop, and cocozelle; and in winter squash: acorn, jack o'lantern pumpkin, and delicata. Also included was a breeding line (G-92-730) that segregates for striped and yellow fruit (caserta/ yellow type), and one (G-92-622) that segregates for striped and green fruit (caserta/zucchini type). Cornell Univ. squash breeding lines were included from the Geneva ( $R$. Robinson) and Ithaca (M. Kyle) breeding programs, selected to represent a broad range of fruit types (Tables 1 and 2). Much of the breeding work at both locations has involved interspecific crosses to bring in virus resistance [C. moschata (Duchesne) Poiret, $C$. ecuadorensis Cutler \& Whitaker, and $C$. martinezii Bailey] and powdery mildew resistance (C. martinezii), thus the pedigrees of these lines are complex. The progenitor species are provided for each breeding line, but in most cases, considerable selection through generations of inbreeding and backcrossing has occurred so the lines generally resemble $C$. pepo types and are predominantly derived from this species.

In 1992, 36 C. pepo genotypes were evaluated for preference (as reflected by beetle infestation per plant and leaf defoliation) by striped cucumber beetle. Genotypes were seeded on 17 June into 50-cell flats containing Promix BX (Premier Brands, Yonkers, N.Y.) in a greenhouse maintained at $\approx 28 \mathrm{C}$, except as noted below. Flats were transferred to a cold frame 10 days later where they remained until transplanting. On 1 July, when plants had one or two true leaves, they were transplanted to field plots. The soil type was fine, illitic, mesic, Aeric, Epiaqualf [U.S. Dept. of Agriculture (USDA), 1994]. A complete commercial fertilizer, $13 \mathrm{~N}-13 \mathrm{P}-13 \mathrm{~K}$, was banded in the field row on 30 June at a rate of 337 $\mathrm{kg} \cdot \mathrm{ha}^{-1}$. No pesticides were applied at any time during the study.

Because cucurbitacin content can change rapidly with seedling development (Jaworski et al., 1985), evaluations of preference by cucumber beetles were conducted as early as possible. Since emergence rates vary among field-grown genotypes, those emerging earlier can incur more beetle damage than those emerging later. To minimize this potential bias, transplant size was standardized by placing the more rapidly developing seedlings under slightly cooler greenhouse conditions (20C) to retard growth.

A randomized complete-block design was used with five replications per genotype. Each replication consisted of a single row of five hills spaced $0.91 \mathrm{~m}$ apart. Rows were spaced $1.83 \mathrm{~m}$ apart. The hills were thinned to one 
plant each 4 days after transplanting, resulting in a total of 25 plants for each genotype.

On 15-16 and 22-23 July, when plants had two to three and four to five true leaves, respectively, all plants in every plot were inspected and the number of striped and spotted cucumber beetles per plant were recorded separately. In addition, the extent of defoliation (leaf area consumed by beetles) of each leaf of every plant was rated on a scale of 0 to $5(0=0 \%, 1=$ greater than or equal to $1 \leq 20 \%$, $2=$ greater than or equal to $20 \% \leq 40 \%, 3=$ greater than or equal to $40 \% \leq 60 \%, 4=$ greater than or equal to $60 \% \leq 80 \%, 5=$ greater than or equal to $80 \% \leq 100 \%$ defoliation). Average leaf defoliation ratings were calculated for each plant and averaged across replications.
In 1994, 40 C. pepo genotypes were evaluated. Seeding was conducted as in 1992, but delayed until 28 July to improve chances for increased beetle populations in the field. Transplants were handled and fertilized as described for 1992. On 11 Aug., seedlings at the first true-leaf stage were transplanted to field plots. The soil type was loamy-skeletal, mixed, mesic, Glossoboric, Hapludalf (USDA, 1994). No pesticides were applied following transplanting. The experimental design was as in 1992. All plants were inspected on 22-23 Aug. and 2 Sept., when plants had one to two and four to five true leaves, respectively, and the number of corn rootworm and cucumber beetles per plant and extent of defoliation of each plant were recorded as in 1992.
Genotypes were divided into groups according to fruit types, for purposes of statistical analyses. Analysis of variance (ANOVA) was conducted to determine if differences existed in number of beetles/plant, proportion of infested plants, and defoliation ratings between and within fruit types. Means were separated using LSD at $P \leq 0.05$. In 1992, a repeated-measure ANOVA was used to analyze differences among fruit types in beetle infestation and defoliation and for interaction with date. In 1994, only data from 22 to 23 Aug. were analyzed because beetle counts were extremely low on 2 Sept. To determine if defoliation ratings, proportion of infested plants, and number of beetles/plant were correlated, we conducted linear correlation analy-

Table 1. Infestation and defoliation of Cucurbita pepo cultivars and breeding lines by striped cucumber beetle (Freeville, N.Y., 1992).

\begin{tabular}{|c|c|c|c|c|c|c|c|}
\hline \multirow[b]{3}{*}{ Fruit type } & \multirow[b]{3}{*}{ Line/cultivar } & \multicolumn{6}{|c|}{ Rating date } \\
\hline & & \multicolumn{3}{|c|}{ 15-16 July } & \multicolumn{3}{|c|}{ 22-23 July } \\
\hline & & $\begin{array}{l}\begin{array}{l}\text { Beetles/plant } \\
\text { (no.) }\end{array} \\
\end{array}$ & $\begin{array}{c}\text { Infested plants } \\
(\%)\end{array}$ & $\begin{array}{c}\text { Defoliation } \\
\text { rating }^{2}\end{array}$ & $\begin{array}{l}\begin{array}{c}\text { Beetles/plant } \\
\text { (no.) }\end{array} \\
\end{array}$ & $\begin{array}{c}\text { Infested plants } \\
(\%)\end{array}$ & $\begin{array}{c}\text { Defoliation } \\
\text { rating }^{z}\end{array}$ \\
\hline \multirow[t]{3}{*}{ Scallop } & Scallop & $0.48^{\mathrm{Ns}}$ & $28^{\mathrm{NS}}$ & $0.51^{\mathrm{Ns}}$ & $0.32^{\mathrm{Ns}}$ & $20^{\mathrm{Ns}}$ & $0.49^{\mathrm{vs}}$ \\
\hline & Peter Pan & 0.88 & 40 & $0.46 \mathrm{a}$ & 0.36 & 28 & 0.39 \\
\hline & Type mean & $0.68 a^{x}$ & $34 a$ & $0.48 a$ & $0.34 a$ & $24 a b$ & $0.44 a$ \\
\hline Acorn & Royal Acorn & $0.76 a$ & $28 a$ & $0.53 a$ & $0.20 a$ & $20 a$ & $0.35 a$ \\
\hline \multirow{10}{*}{$\begin{array}{l}\text { Yellow } \\
\text { straightneck }\end{array}$} & & & & & & & \\
\hline & Slender Gold & $0.21^{\mathrm{Ns}}$ & $21 \mathrm{a}^{\mathrm{w}}$ & $0.43 \mathrm{a}$ & $0.38 \mathrm{a}$ & $16 \mathrm{a}$ & $0.41 \mathrm{a}$ \\
\hline & Gold Bar & 0.48 & $24 \mathrm{ab}$ & $0.50 \mathrm{a}$ & $0.48 \mathrm{a}$ & $24 \mathrm{ab}$ & $0.48 \mathrm{ab}$ \\
\hline & Yellow crookneck & 0.64 & $24 \mathrm{ab}$ & $0.46 \mathrm{a}$ & $0.48 \mathrm{a}$ & $32 \mathrm{ab}$ & $0.53 \mathrm{ab}$ \\
\hline & $\mathrm{I}-91-575-1^{\mathrm{v}}$ & 0.80 & $40 \mathrm{ab}$ & $0.83 \mathrm{~b}-\mathrm{d}$ & $0.88 \mathrm{a}$ & $36 \mathrm{ab}$ & $0.73 \mathrm{~b}$ \\
\hline & $\begin{array}{l}\text { Early Prolific } \\
\text { straightneck } \\
\text { Sundance }\end{array}$ & 1.48 & $32 \mathrm{ab}$ & $0.67 \mathrm{a}-\mathrm{c}$ & $0.60 \mathrm{a}$ & $24 \mathrm{ab}$ & $0.57 \mathrm{ab}$ \\
\hline & crookneck & 1.64 & $48 \mathrm{a}-\mathrm{c}$ & $0.60 \mathrm{ab}$ & $1.36 \mathrm{a}$ & $40 \mathrm{ab}$ & $0.62 \mathrm{ab}$ \\
\hline & G-92-341"u & 2.28 & $76 \mathrm{c}$ & $1.06 \mathrm{~d}$ & $3.24 \mathrm{~b}$ & $76 \mathrm{c}$ & $1.45 \mathrm{c}$ \\
\hline & I-91-511-1R & 2.56 & $52 \mathrm{bc}$ & $0.89 \mathrm{~cd}$ & $1.36 \mathrm{a}$ & $48 \mathrm{bc}$ & $0.77 \mathrm{~b}$ \\
\hline & Type mean & $1.26 a b$ & $40 a$ & $0.68 a$ & $1.10 a b$ & $37 a-c$ & $0.70 a$ \\
\hline Caserta/yellow & G-92-730u & $3.01 \mathrm{a}-\mathrm{c}$ & $68 \mathrm{~b}$ & $1.16 \mathrm{~b}$ & $1.46 \mathrm{a}-\mathrm{c}$ & $48 \mathrm{~b}-\mathrm{d}$ & $1.47 \mathrm{~b}$ \\
\hline Caserta/zucchini & G-92-622 & $3.04 \mathrm{a}-\mathrm{c}$ & $76 \mathrm{~b}$ & $1.50 \mathrm{c}$ & $2.68 \mathrm{~b}-\mathrm{d}$ & $76 \mathrm{e}$ & $1.62 \mathrm{bc}$ \\
\hline \multirow[t]{17}{*}{ Zucchini } & I-91-504-2L & $1.00^{\mathrm{Ns}}$ & $32^{\mathrm{Ns}}$ & $0.81 \mathrm{ab}$ & $1.92^{\mathrm{Ns}}$ & $48^{\text {vs }}$ & $1.02 \mathrm{ab}$ \\
\hline & I-91-576-1 & 1.68 & 48 & $0.76 \mathrm{a}$ & 0.84 & 40 & $0.84 \mathrm{a}$ \\
\hline & G-92-330u & 2.12 & 48 & $1.31 \mathrm{~cd}$ & 1.44 & 48 & $1.22 \mathrm{a}-\mathrm{c}$ \\
\hline & Black Jack & 2.52 & 72 & $1.10 \mathrm{~b}-\mathrm{d}$ & 2.84 & 44 & $1.38 \mathrm{~b}-\mathrm{d}$ \\
\hline & G-92-309 & 2.56 & 64 & $1.28 \mathrm{~cd}$ & 3.16 & 44 & $1.51 \mathrm{~b}-\mathrm{d}$ \\
\hline & I-91-513 & 2.65 & 70 & $1.12 \mathrm{~b}-\mathrm{d}$ & 3.92 & 60 & $1.44 \mathrm{~b}-\mathrm{d}$ \\
\hline & G-92-563 & 2.68 & 60 & $1.15 \mathrm{~cd}$ & 2.76 & 48 & $1.89 \mathrm{~d}$ \\
\hline & G-92-327u & 3.00 & 68 & $1.04 \mathrm{a}-\mathrm{c}$ & 1.92 & 40 & $1.45 \mathrm{~b}-\mathrm{d}$ \\
\hline & Ambassador & 3.08 & 60 & $1.01 \mathrm{a}-\mathrm{c}$ & 1.40 & 32 & $1.41 \mathrm{~b}-\mathrm{d}$ \\
\hline & G-92-627 & 3.24 & 76 & $1.40 \mathrm{de}$ & 3.92 & 64 & $1.77 \mathrm{~d}$ \\
\hline & Senator & 3.64 & 64 & $1.18 \mathrm{~cd}$ & 2.36 & 60 & $1.64 \mathrm{~cd}$ \\
\hline & President & 4.28 & 82 & $1.27 \mathrm{~cd}$ & 0.82 & 36 & $1.56 \mathrm{~cd}$ \\
\hline & Dark Green & 4.40 & 72 & $1.32 \mathrm{~cd}$ & 2.88 & 56 & $1.67 \mathrm{~cd}$ \\
\hline & Embassy Green & 5.32 & 72 & $1.07 \mathrm{a}-\mathrm{c}$ & 2.92 & 52 & $1.23 \mathrm{a}-\mathrm{c}$ \\
\hline & G-92-306 & 5.56 & 64 & $1.24 \mathrm{~cd}$ & 1.76 & 52 & $1.45 \mathrm{~b}-\mathrm{d}$ \\
\hline & G-92-322 & 5.82 & 88 & $1.68 \mathrm{e}$ & 4.04 & 79 & $2.58 \mathrm{e}$ \\
\hline & Type mean & $3.32 b c$ & $65 b$ & $1.17 b$ & $2.43 b-d$ & $50 \mathrm{~cd}$ & $1.50 \mathrm{~b}$ \\
\hline \multirow[t]{7}{*}{ Caserta } & G-92-562 & $2.52^{\mathrm{Ns}}$ & $64^{\text {ss }}$ & $0.99 \mathrm{a}$ & $3.68 \mathrm{ab}$ & $48^{\mathrm{Ns}}$ & $1.02 \mathrm{a}$ \\
\hline & Cocozelle & 3.32 & 60 & $1.16 \mathrm{ab}$ & $1.88 \mathrm{a}$ & 64 & $1.26 \mathrm{a}$ \\
\hline & G-92-572 & 3.60 & 72 & $1.55 \mathrm{c}$ & $2.12 \mathrm{a}$ & 64 & $2.69 \mathrm{c}$ \\
\hline & I-91-507 & 3.60 & 76 & $1.33 \mathrm{bc}$ & $1.28 \mathrm{a}$ & 40 & $1.59 \mathrm{ab}$ \\
\hline & Caserta & 5.20 & 76 & $1.37 \mathrm{bc}$ & $5.68 \mathrm{~b}$ & 80 & $2.63 \mathrm{c}$ \\
\hline & G-92-624 & 6.52 & 83 & $1.54 \mathrm{c}$ & $5.94 \mathrm{~b}$ & 84 & $2.05 \mathrm{~b}$ \\
\hline & Type mean & $4.12 c$ & $72 b$ & $1.33 b c$ & $3.43 d$ & $63 \mathrm{de}$ & $1.87 c$ \\
\hline $\begin{array}{l}\text { Precocious yellow } \\
\text { straightneck }\end{array}$ & Gold Rush & $7.44 d$ & $88 b$ & $1.34 b c$ & $3.00 \mathrm{~cd}$ & $76 e$ & $1.79 b c$ \\
\hline
\end{tabular}

${ }^{2}$ Based on leaf area consumed by beetles, rated on a scale of $0-5(0=0 \%, 1=$ greater than or equal to $1 \% \leq 20 \%, 2=$ greater than or equal to $20 \% \leq 40 \%, 3=$ greater than or equal to $40 \% \leq 60 \%, 4=$ greater than or equal to $60 \% \leq 80 \%, 5$ = greater than or equal to $80 \% \leq 100 \%$ defoliation).

${ }^{y}$ Mean of all breeding lines, cultivars, or both within a fruit type.

${ }^{x}$ Mean separation of fruit types by LSD test, $P \leq 0.05$, shown in italics.

"Mean separation of cultivars and breeding lines within a fruit type by LSD test, $P \leq 0.05$, not italicized.

"Breeding line progenitor species are C. martinezii $\mathrm{x}$ C. pepo, unless otherwise indicated. "G" and "I" prefixes indicate breeding programs at Geneva and Ithaca. "Breeding line progenitor species are C. ecuadorensis x C. pepo.

${ }^{\mathrm{N}}$ Nonsignificant. 
Table 2. Infestation and defoliation of Cucurbita pepo cultivars and breeding lines by cucumber and corn rootworm beetles (Freeville, N.Y., 1994).

\begin{tabular}{|c|c|c|c|c|}
\hline Fruit type & Line/cultivar & $\begin{array}{l}\text { Beetles/plant } \\
\text { (no.) }\end{array}$ & $\begin{array}{c}\text { Infested plants } \\
(\%)\end{array}$ & $\begin{array}{c}\text { Defoliation } \\
\text { rating }^{z}\end{array}$ \\
\hline Acorn & Royal Acorn & $0.04 a^{y}$ & $4 a$ & $0.20 a$ \\
\hline \multirow[t]{3}{*}{ Pumpkin } & I-93-2028 & $0.00^{\mathrm{Ns}}$ & $0^{\text {ss }}$ & $0.06^{\mathrm{NS}}$ \\
\hline & I-93-2024 & 0.08 & 8 & 0.16 \\
\hline & Tyре mean ${ }^{w}$ & $0.04 a$ & $4 a$ & $0.11 a$ \\
\hline Delicata & I-92-581-4 & $0.12 a$ & $12 a$ & $0.12 a$ \\
\hline \multirow{6}{*}{$\begin{array}{l}\text { Yellow } \\
\text { straightneck }\end{array}$} & & & & \\
\hline & I-93-238 & $0.04 \mathrm{a}^{\mathrm{v}}$ & $4^{\mathrm{Ns}}$ & $0.26 \mathrm{a}$ \\
\hline & I-93-239-R & $0.04 \mathrm{a}$ & 4 & $0.04 \mathrm{a}$ \\
\hline & G-94-186u & $0.08 \mathrm{a}$ & 8 & $0.24 \mathrm{a}$ \\
\hline & G-94-31"u & $0.76 \mathrm{~b}$ & 29 & $1.22 \mathrm{~b}$ \\
\hline & Type mean & $0.23 a b$ & $11 a$ & $0.44 a$ \\
\hline \multirow[t]{25}{*}{ Zucchini } & G-94-113 & $0.12^{\mathrm{vs}}$ & $12^{\text {Ns }}$ & $0.22 \mathrm{a}$ \\
\hline & G-94-40" & 0.20 & 20 & $0.14 \mathrm{a}$ \\
\hline & G-94-53" & 0.20 & 20 & $0.34 \mathrm{ab}$ \\
\hline & G-94-25u & 0.28 & 28 & $1.26 \mathrm{c}-\mathrm{e}$ \\
\hline & G-94-85" & 0.36 & 20 & $1.18 \mathrm{~cd}$ \\
\hline & Black Jack & 0.44 & 27 & $1.60 \mathrm{c}-\mathrm{f}$ \\
\hline & G-94-434 & 0.44 & 16 & $1.12 \mathrm{bc}$ \\
\hline & G-94-177 & 0.44 & 32 & $1.72 \mathrm{c}-\mathrm{f}$ \\
\hline & G-94-23“u & 0.48 & 40 & $2.02 \mathrm{ef}$ \\
\hline & G-94-117 & 0.50 & 31 & $1.78 \mathrm{c}-\mathrm{f}$ \\
\hline & G-94-114"u & 0.50 & 35 & $1.16 \mathrm{bc}$ \\
\hline & G-94-12 u & 0.52 & 34 & $1.86 \mathrm{c}-\mathrm{f}$ \\
\hline & G-94-430 & 0.52 & 43 & $2.04 \mathrm{ef}$ \\
\hline & G-94-484 & 0.60 & 56 & $2.28 \mathrm{f}$ \\
\hline & G-94-164" & 0.68 & 32 & $1.82 \mathrm{c}-\mathrm{f}$ \\
\hline & G-94-10" & 0.72 & 30 & $2.02 \mathrm{ef}$ \\
\hline & G-94-481 & 0.80 & 64 & $1.76 \mathrm{c}-\mathrm{f}$ \\
\hline & G-94-91"u & 0.80 & 40 & $1.56 \mathrm{c}-\mathrm{f}$ \\
\hline & G-94-29u & 0.86 & 53 & $1.22 \mathrm{c}-\mathrm{e}$ \\
\hline & G-94-21" & 0.88 & 40 & $1.86 \mathrm{c}-\mathrm{f}$ \\
\hline & I-93-2005 & 1.06 & 35 & $1.38 \mathrm{c}-\mathrm{e}$ \\
\hline & I-93-2006 & 1.14 & 34 & $1.80 \mathrm{c}-\mathrm{f}$ \\
\hline & G-94-80" & 1.24 & 52 & $1.16 \mathrm{bc}$ \\
\hline & G-94-146" & 1.38 & 92 & $2.00 \mathrm{~d}-\mathrm{f}$ \\
\hline & Type mean & $0.62 a b$ & $37 b$ & $1.47 b c$ \\
\hline \multirow[t]{8}{*}{ Caserta } & G-94-431 & $0.04 \mathrm{a}$ & $4 \mathrm{a}$ & $0.34 \mathrm{a}$ \\
\hline & G-94-424 & $0.52 \mathrm{ab}$ & $29 \mathrm{~b}$ & $0.90 \mathrm{ab}$ \\
\hline & G-94-466 & $0.56 \mathrm{ab}$ & $32 \mathrm{~b}$ & $1.24 \mathrm{a}-\mathrm{c}$ \\
\hline & G-94-446 & $0.56 \mathrm{ab}$ & $44 \mathrm{bc}$ & $1.44 \mathrm{bc}$ \\
\hline & I-93-2009 & $1.06 \mathrm{a}-\mathrm{c}$ & $40 \mathrm{bc}$ & $1.28 \mathrm{a}-\mathrm{c}$ \\
\hline & I-93-2007 & $1.54 \mathrm{bc}$ & $75 \mathrm{~d}$ & $1.92 \mathrm{c}$ \\
\hline & I-93-2008 & $1.80 \mathrm{c}$ & $56 \mathrm{~cd}$ & $1.84 \mathrm{bc}$ \\
\hline & Tyре mean & $0.87 b$ & $40 \mathrm{~b}$ & $1.28 b$ \\
\hline \multirow{4}{*}{$\begin{array}{l}\text { Precocious yellow } \\
\text { straightneck }\end{array}$} & & & & \\
\hline & G-94-77 & $0.54 \mathrm{a}$ & $27 \mathrm{a}$ & $1.34 \mathrm{a}$ \\
\hline & G-93-633 & $2.68 \mathrm{~b}$ & $57 \mathrm{~b}$ & $2.78 \mathrm{~b}$ \\
\hline & Type mean & $1.61 \mathrm{c}$ & $42 b$ & $2.06 c$ \\
\hline
\end{tabular}

${ }^{2}$ Based on leaf area consumed by beetles, rated on a scale of $0-5(0=0 \%, 1=$ greater than or equal to $1 \%$ $\leq 20 \%, 2=$ greater than or equal to $20 \% \leq 40 \%, 3=$ greater than or equal to $40 \% \leq 60 \%, 4=$ greater than or equal to $60 \% \leq 80 \%, 5=$ greater than or equal to $80 \% \leq 100 \%$ defoliation)

${ }^{y}$ Mean separation of fruit types by LSD test, $P \leq 0.05$, shown in italics.

"Breeding line progenitor species are C. martinezii x C. pepo, unless otherwise indicated. "G" and "I" prefixes indicate breeding programs at Geneva and Ithaca.

wMean of all breeding lines, cultivars, or both within a fruit type.

"Mean separation of cultivars and breeding lines within a fruit type by LSD test, $P \leq 0.05$, not italicized.

"Breeding line progenitor species are C. ecuadorensis $\times$ C. pepo.

${ }^{\mathrm{Ns}}$ Nonsignificant.

ses using the mean values of five replications of each genotype.

\section{Results and Discussion}

In 1992, >99\% of all beetles recorded were striped cucumber beetles; the balance were spotted cucumber beetles. Repeated-measures ANOVA indicated a significant date $\times$ fruit type interaction for beetles/plant and defoliation ratings $(\mathrm{F}=3.21, \mathrm{df}=7,32, P=0.011$ and $\mathrm{F}=3.90, \mathrm{df}=7,32, P=0.004$, respectively) in 1992 (data not presented). Therefore, results low straightneck fruit type, represented by 'Gold Rush', had the most striped cucumber beetles (Table 1). On 22-23 July, differences among fruit types were less distinct, with caserta/zucchini, zucchini, caserta, and precocious yellow straightneck having more beetles than other types. Scallop and acorn fruit types generally had fewer beetles on both dates. Caserta/yellow, caserta/zucchini, zucchini, caserta, and precocious yellow straightneck fruit types were the most defoliated on 15-16 and 22-23 July, while scallop, acorn, and yellow straightneck types were the least defoliated.

In 1994, beetle counts taken from all Cucurbita were pooled for analyses because there were few of some species. Of 580 beetles recorded, $75 \%$ were spotted cucumber beetle, $13 \%$ were western corn rootworm, $7 \%$ were striped cucumber beetle, and 5\% were northern corn rootworm. The presence of spotted cucumber beetles and corn rootworms in 1994 was due to the later planting date (Hoffmann, 1993). The precocious yellow straightneck type had the most beetles and the most defoliation (Table 2); however, this type was represented by only two breeding lines (G-94-77 and G-93-633). The least defoliated types were pumpkin, delicata, acorn, and yellow straightneck.

In 1992 and 1994, significant differences in defoliation by beetles existed within yellow straightneck, zucchini, and caserta fruit types, indicating that genetic variation for cucumber beetle preference within these fruit types exists (Tables 1 and 2). In general, beetle defoliation and infestation of fruit types was similar between years even though the dominant beetle species was striped cucumber beetle in 1992 and spotted cucumber beetle in 1994.

For each of the three dates plants were sampled, there were significant positive linear correlations between percentage of infested plants and beetles/plant $(r \geq 0.77)$, percentage of infested plants and defoliation ratings $(r \geq$ $0.78)$, and defoliation ratings and beetles/plant $(r \geq 0.72)(\mathrm{df}=34$ in 1992,38 in 1994, $P<$ 0.001 ). The positive correlation between these three variables indicates that beetle populations are a good predictor of defoliation and proportion of plants infested.

Our data indicate that precocious yellow, caserta, zucchini, caserta/zucchini, and caserta/ yellow fruit types were the most infested and defoliated fruit types. In general, zucchini has higher cucurbitacin levels than other fruit types (Ferguson et al., 1983 ), and our results indicate that the caserta and precocious yellow fruit type also may possess high cucurbitacin levels. However, fruit type is not necessarily associated with cucurbitacin levels or beetle preference, since genes that determine fruit type have been bred into various genetic backgrounds showing wide variation in beetle preference.

Some genotypes were highly preferred by cucumber beetles in both years and have the potential to be used as trap crops. This tactic, which has been recommended for many years (Headlee, 1908), holds great potential because aggregation is greatest on preferred genotypes 
(Metcalf et al., 1982) and beetles are unlikely to disperse once established on plants (Bach 1989). Radin and Drummond (1994) reported promising results when a squash trap crop was used to manage striped cucumber beetles in cucumber. An additional advantage may be achieved by planting the trap crop earlier than the main crop. Our data indicate that early plantings of cucumbers have higher levels of infestation than ones emerging only a few days later.

The germplasm identified in this study may be used for reducing pesticide use in cucurbits through the development of cultivars with disease and insect resistance. A range of preferences by diabroticite beetle pests in squash has been quantified that can be used to minimize crop damage through reduced preference or through manipulation of beetle infestations (trap crops).

\section{Literature Cited}

Bach, C.E. 1977. Distribution of Acalymma vittata and Diabrotica virgifera virgifera (Coleoptera: Chrysomelidae) on cucurbits. Great Lakes Entomol. 10:123-125.

Bach, C.E. 1989. Chrysomelid beetle movements in relation to host-plant size and surrounding nonhost vegetation. Ecology 70:1679-1690.

Chambliss, O.L. and C.M. Jones. 1966. Chemical and genetic basis for insect resistance in cucurbits. Proc. Amer. Soc. Hort. Sci. 89:394-405.
Cornell Cooperative Extension. 1995. Pest management recommendations for commercial vegetable and potato production. Cornell Coop. Ext. Publ., Cornell Univ., Ithaca, N.Y.

Da Costa, C.P. and C.M. Jones. 1971. Resistance of cucumber, Cucumis sativus L., to three species of cucumber beetles. HortScience 6:340-343.

Ferguson, J.E., E.R. Metcalf, R.L. Metcalf, and A.M. Rhodes. 1983. Influence of cucurbitacin content in cotyledons of Cucurbitaceae cultivars upon feeding behavior of Diabroticina beetles (Coleoptera: Chrysomelidae). J.Econ. Entomol. 76:47-51.

Gergerich, R.C., H.A. Scott, and J.P. Fulton. 1986. Evaluation of Diabrotica beetles as vectors of plant viruses, p. 227-250. In: J.L. Krysan and T.A. Miller (eds.). Methods for the study of pest Diabrotica. Springer-Verlag, New York.

Gorski, P.M., A. Jaworski, S. Shannon, and R.W. Robinson. 1986. Rapid TLC and HPLC quantification of cucurbitacin $\mathrm{C}$ in cucumber cotyledons. HortScience 21:1034-1036.

Headlee, T.J. 1908. Life history of the striped cucumber beetle with a brief account of some experiments for its control. J. Econ. Entomol. 1:203-209.

Hoffmann, M.P. 1993. Cucumber beetles and corn rootworms in vine crops, p. 32-35. In: Proc. New York State Veg. Conf. 2-4 Feb. 1993, Syracuse.

Howe, W.L., J.R. Sanborn, and A.M. Rhodes. 1976. Western corn rootworm adult and spotted cucumber beetle associations with Cucurbita and cucurbitacins. Environ. Entomol. 5:1043-1048. Jaworski, A., P.M. Gorski, S. Shannon, and R.W.
Robinson. 1985. Cucurbitacin concentrations in different plant parts of Cucurbita species as a function of age. Cucurbit Genetics Coop. Rpt. 8:71-73.

Metcalf, R.L. and E.R. Metcalf. 1992. Diabroticite rootworm beetles, p. 64-108. In: T.A. Miller and H.F. van Emden (eds.). Plant kairomones in insect ecology and control. Chapman \& Hall, New York.

Metcalf, R.L. and A.M. Rhodes. 1990. Coevolution of the Cucurbitaceae and Luperini (Coleoptera: Chrysomelidae): Basic and applied aspects, $\mathrm{p}$. 167-182. In: D.M. Bates, R.W. Robinson, and C. Jeffrey (eds.). Biology and utilization of the Cucurbitaceae. Comstock Publ. Assn., Cornell Univ. Press, Ithaca, N.Y., and London.

Metcalf, R.L., A.M. Rhodes, R.A. Metcalf, J.E. Ferguson, E.R. Metcalf, and P. Lu. 1982. Curcurbitacin contents and Diabroticite (Coleoptera: Chrysomelidae) feeding upon Cucurbita spp. Environ. Entomol. 11:931937.

Radin, A.M. and F.A. Drummond. 1994. An evaluation of the potential for the use of trap cropping for control of the striped cucumber beetle, Acalymma vittata (F.) (Coleoptera: Chrysomelidae). J. Agr. Entomol. 11:95-113.

Rand, R.V. 1916. Transmission and control of bacterial wilt of cucurbits. J. Agr. Res. 6:417-434.

Robinson, R.W. 1992. Genetic resistance in the Cucurbitaceae to insects and spider mites. Plant Breeding Rev. 10:309-360.

U.S. Dept. of Agriculture. 1994. Keys to soil taxonomy, 6th ed. Soil Survey Staff, U.S. Dept. Agr., Washington, D.C. 